Board of Governors of the Federal Reserve System

International Finance Discussion Papers

Number 632

December 1998

\title{
THE IMPLICATIONS OF RISK MANAGEMENT INFORMATION SYSTEMS FOR THE ORGANIZATION OF FINANCIAL FIRMS
}

\author{
Michael S. Gibson
}

NOTE: International Finance Discussion Papers are preliminary materials circulated to stimulate discussion and critical comment. References to International Finance Discussion Papers (other than an acknowledgment that the writer has had access to unpublished material) should be cleared with the author or authors. Recent IFDPs are available on the Web at www.federalreserve.gov. 


\title{
THE IMPLICATIONS OF RISK MANAGEMENT INFORMATION SYSTEMS FOR THE ORGANIZATION OF FINANCIAL FIRMS
}

\author{
Michael S. Gibson ${ }^{*}$
}

\begin{abstract}
Financial dealer firms have invested heavily in recent years to develop information systems for risk measurement. I take it as given that technological progress is likely to continue at a rapid pace, making it less expensive for financial firms to assemble risk information. I look beyond questions of risk measurement methodology to investigate the implications of risk management information systems. By examining several theoretical models of the firm in the presence of asymmetric information, I explore how a financial firm's capital budgeting, incentive compensation, capital structure, and risk management activities are likely to change as it becomes less costly to assemble risk information. I also explore the likely effects of the falling cost of assembling risk information on a financial firm's organizational structure. Two common themes emerge: centralization within the firm and increased disclosure of risk information outside the firm are both likely to increase.
\end{abstract}

Keywords: asymmetric information, value at risk, capital budgeting, incentive compensation, capital structure, organizational structure.

\footnotetext{
*Email: michael.s.gibson@ frb.gov. Prepared for the Second Joint Central Bank Research Conference on Risk Measurement and Systemic Risk, Bank of Japan, November 16-17, 1998. The author is a staff economist in the Division of International Finance. The views in this paper are solely the responsibility of the author and should not be interpreted as reflecting the views of the Board of Governors of the Federal Reserve System or of any other person associated with the Federal Reserve System.
} 


\section{Introduction}

Financial dealer firms have invested heavily in recent years to develop information systems for risk measurement and management. ${ }^{1}$ These systems gather data on a firm's risk positions and compute statistical measurements, such as Value-at-Risk, to assess the magnitude of the risks faced by the firm. Increasingly, the uses of these information systems go beyond measurement. They are now beginning to be used for capital allocation and incentive compensation.

Previous literature, such as Gibson (1997), discussed how risk management information systems make it possible for financial firms to improve their risk measurement by adopting new measurement methodologies. This literature also discussed the tradeoffs between different risk measurement methodologies and how those tradeoffs depend on the way information systems are designed. ${ }^{2}$ In this paper, we take it as given that technological progress in computer technology and telecommunications is likely to continue at a rapid pace, making it less expensive to assemble risk information. We look at a broader set of issues and ask what the implications of risk management information systems are likely to be for the operation of financial dealer firms.

The paper has two parts. The first looks at the role that information plays in economic models of a firm's capital budgeting, incentive compensation, capital structure, and risk management decisions. Specifically, we look at models whose assumptions make them relevant

${ }^{1}$ According to a report by Meridien Research, Inc., the market for firmwide risk management systems was estimated at \$572 million in 1997.

${ }^{2}$ See also Pritsker (1997). 
to a discussion of financial (dealer) firms and look at what happens in the models, when the cost of transmitting or assembling information declines.

The second part of the paper looks at the role that information plays in determining a firm's organzational structure. While the effects of lower costs of assembling information are again the focus, this part relies on less formal arguments, including an analogy with past revolutions in information systems technology.

\section{Risk management information systems and economic models of the firm}

Economists have focused on the roles that asymmetric information plays in many aspects of a firm. The approach in this part of the paper is to take models of asymmetric information that apply to financial firms and see what happens when the cost of collecting and transmitting information falls. We make no attempt at a complete survey of papers relying on asymmetric information. Rather, we choose a few areas to investigate. We consider information flows both within a firm and outside a firm.

First, we consider information flows within a firm. Introducing terminology, we will refer to the firm's residual claimant as the principal or owner, and to those who actually make decisions on risk-taking as the agent or manager. The need to deal with asymmetric information within a firm motivates the study of capital budgeting, capital structure, risk management, and incentive compensation, among other topics. To put it another way, all these things would be either unnecessary or less complicated if owners and managers had the same information.

$\underline{\text { Incentive compensation }}$

Hirshleifer and Suh (1992) model a situation where a manager makes two choices: how 
risky of an investment to make and what level of effort to put forth. The owner can only observe the investment's output. Hirshleifer and Suh solve for the optimal incentive contract, which must give the manager an incentive both to choose the owner's preferred project (risky or not risk) and to exert effort. They show that, in general, the optimal contract depends on several factors, including the nature of the risky projects, how the manager's effort affects the probability of good outcomes, and the curvature of the manager's utility function. One way the owner can influence the choice of project is by changing the curvature of the incentive contract. Another way is by hiring managers with a particular type of risk preference.

Hirshleifer and Suh (1992, p. 323) conclude that their "analysis implies that firms with desirable risky growth opportunities ... should attempt to hire managers with preferences that promote risk-taking." The reason why this is true, in the model, is that when there are likely to be a lot of profitable but risky investments coming along, owners want to give managers an incentive to take risk. One way to do this is by providing strongly convex incentive compensation. But this also forces managers to bear a lot of risk. To reduce the disutility of having a manager bear so much risk, it is efficient to hire managers who are not too risk-averse. This could be an explanation for the "Liars Poker" phenomenon (i.e., financial dealer firms have a lot of apparently risk-loving employees).

One way to capture the effect of risk management information systems in Hirshleifer and Suh's model would be to allow the owner to observe the riskiness of the investment project chosen by the manager, but not to observe managerial effort. In other words, the lower cost of information removes the need to delegate all authority over project choice to the manager. Hirshleifer and Suh (1992, Section 4) compare the optimal incentive contract with and without 
asymmetric information on project choice, in the case where the owner prefers the riskier project. With symmetric information, the owner can require the manager to choose the risky project. With asymmetric information, the owner must induce this choice, by means of the incentive contract.

The owner can choose one of two ways to induce the manager to choose the risky project. First, the owner can make the contract more convex than in the case of symmetric information. However, effort may be distorted as a result. Second, the owner can hire a manager who is not very risk-averse and keep the same contract as in the case of symmetric information.

Asymmetric information introduces distortions, such as hiring risk-loving traders and implementing more convex incentive contracts. If information becomes less asymmetric as a result of risk management information systems, two implications arise from the model. First, there will be less of a need to hire risk-loving traders. Second, incentive contracts can become less convex, because owners can centralize information on risk positions and can observe whether risky investments are desirable or not, rather than leaving that choice up to managers. Capital budgeting

Harris and Raviv (1996) study the problem of capital budgeting in an environment of asymmetric information. Capital budgeting is the problem of how a firm allocates capital to its business units for investment. In their model, the manager of a business unit, but not the firm's owner, has information on the investment technology. The owner must decide how to allocate capital to the manager. It is assumed that the owner can audit the manager, at a cost, to verify what investment technology is available to the manager. Following an audit, capital can be allocated on the basis of the audit results. The manager is assumed to receive perks related to the 
size of his investment, so he always prefers overinvestment. The manager's preference for overinvestment creates a distortion that the capital budgeting process aims to reduce.

The optimal capital budgeting process has the manager's capital allocation increasing when the manager claims to have a high productivity investment opportunity, and for the probability of auditing by the owner rising with the size of the manager's capital budget. Harris and Raviv provide an interpretation of the optimal contract: the manager is assigned a "limit" which is calibrated to the amount of capital needed to exploit a low productivity investment opportunity. The manager can choose from a menu of "limit increases" if he has access to a higher productivity investment opportunity. The owner randomly chooses to either grant a higher limit or audit the manager's claim of a higher productivity production technology (and assign capital according to the outcome of the audit).

Harris and Raviv's model is attractive because it seems to capture some of the features of real-world capital budgeting within dealer firms. To capture the implications of risk management information systems in their model, we can ask what happens in their model when it becomes cheaper for the owner to access information on the manager's investment opportunities. According to their model, holding other things constant, a lower cost of auditing will lead to a lower initial spending limit, a less rigid capital budgeting system (more choices on the menu of limit increases), a higher probability of auditing, and higher salaries for managers. (Because more auditing reduces the perks that managers earn from overinvestment, managers' salaries must be raised to allow them to earn their reservation wage.) In general, risk management information systems let owners keep managers on a tighter leash and come closer to the first-best investment decisions. 


\section{$\underline{\text { Risk management }}$}

Risk management was the original motivation for the development of sophisticated information systems to measure risk-taking activities. These information systems have allowed financial firms to better monitor and control the risks taken by various parts of the firm. This is true both at the level of the individual trading desk, monitoring its traders, and the firm as a whole, monitoring its business units.

One model of the risk management process in financial firms is presented by Froot and Stein (1998). They model a financial firm's hedging decision under the assumption that the firm behaves as if it is risk averse (perhaps because it faces costs of raising external equity). They show that a firm should hedge any tradeable risks (those that can be sold into the market at a fair price). A position's non-tradeable risk should be priced depending on two factors: the covariance of the non-tradeable risk with the other non-tradeable risks in the firm's portfolio, and the firm's risk aversion, which is a function of its equity-asset ratio and the cost of raising new equity.

Froot and Stein's model implies that the key quantity to be captured by risk management information systems is the covariance of all risks taken within the firm. In order to evaluate a potential investment, its covariance with the existing portfolio of non-tradeable risks must be measured. For this to occur, centralization of risk information is required. Froot and Stein point out that while frequent centralization of risk information is desirable, its benefits must be measured against its cost. We can conclude that, as the cost of information-gathering continues to fall, financial firms will increase the degree of centralization of risk information to improve the effectiveness of risk management. 


\section{$\underline{\text { Capital structure }}$}

The discussion so far has addressed the role of information within the firm. Asymmetric information is also a feature of the relationship between the firm and providers of external funds. Myers and Majluf (1984) model a firm's decision on how to finance an investment project when the firm's insiders have information that outside providers of funds do not have. Their model leads to the "pecking order" theory of capital structure, namely that firms prefer debt finance to equity finance because the value of debt is less sensitive to information about the firm's condition than equity. Moreover, the firm's insiders will refuse to sell equity to outsiders when they perceive that equity to be undervalued by the stock market. This has two implications. First, underinvestment occurs because good projects are passed over when raising equity is made too costly by asymmetric information. Second, when a firm does issue equity it will be interpreted by the market as a negative signal about that firm's prospects. If undervalued firms won't sell equity, any firm that does sell equity must be overvalued, hence its stock price falls. A great deal of empirical evidence supports this theory and supports the conclusion that asymmetric information between a firm's insiders and providers of external funds is important. ${ }^{3}$ There is evidence that the stock market puts a lower value on large dealer firms than on specialist financial firms where asymmetries of information are likely to be smaller. ${ }^{4}$

Risk management information systems have the potential to reduce this information gap. Financial firms have begun to use their risk management information systems to make their

${ }^{3}$ See Masulis (1988) for a survey of the evidence. Of course, other factors affect a firm's choice of capital structure such as taxes, bankruptcy costs, and a desire to limit agency costs between shareholders and managers.

${ }^{4}$ Economist, "The trials of megabanks," October 31, 1998, pp. 23-25. 
operations more transparent. Annual reports of financial firms have increasingly cited quantitative data on the firm's risk-taking activities, such as daily Value-at-Risk, over the past few years. ${ }^{5}$ However, firms' disclosures focus more on the process of managing risk rather than the particular areas in which a firm chooses to risk its capital. This may be due to concerns about divulging proprietary trading strategies in niche markets.

It seems clear that these disclosures do not go far enough to significantly reduce the information gap between insiders and outsiders. For example, there does not seem to be any empirical evidence that a financial firm with more comprehensive risk disclosures in its annual report faces a lower cost of raising new equity.

Asymmetric information models of capital structure make it clear that the benefit of a reduced asymmetry of information would be to keep a firm closer to its first-best level of investment by reducing the wedge between the cost of internal funds and external funds. Another way that information disclosure could lower a firm's cost of capital, discussed by Diamond and Verrecchia (1991), is to increase the liquidity of its securities. The cost of reducing the asymmetry of information would reflect the marginal investment in information technology required to provide the information to outsiders (above the investment the firm needs for internal management purposes), plus the loss of profits from proprietary investment strategies that are revealed to outsiders. It seems likely that the former cost would be small but the latter cost could be large.

Increased standardization of the outputs of risk management information systems would also be required before information could be shared with outsiders at a low cost. Currently there

${ }^{5}$ BIS (1997). 
is little standardization of risk management information systems across firms. While risk measurement systems all rely on a common theory to support them, the particular ways that dealer firms choose to develop their systems are heterogeneous, as are the assumptions used to produce risk measurements. Outputs of risk measurement information systems are equally diverse. For firms that do not develop their own in-house systems, there are many software companies that sell risk management systems which are equally non-standardized.

U.S. financial accounting standards were created in the early 1900s when technological change increased the efficient scale of business operation and required firms to raise significant funds from outsiders. ${ }^{6}$ Accounting standards serve to make financial statements (somewhat) comparable across firms. If technological change is causing changes in the financial system comparable to what happened to the real economy in the early 1900s, a similar standard-setting exercise may be needed for risk information. Suppliers of outside funds to financial firms may come to require a certain amount of standardization of reporting on risk-taking activities.

"Generally Accepted Risk Principles" may have to be developed to complement "Generally Accepted Accounting Principles."7

Incentive Compensation 2

An empirical paper dealing with incentive compensation for risk-taking is Chevalier and Ellison (1997). They show that the relationship between a mutual fund's annual performance and the next year's inflows to the fund is nonlinear: above average performance is rewarded by more

${ }^{6}$ See Johnson (1991).

${ }^{7}$ The accounting firm Coopers and Lybrand recently published a set of risk management principles labeled "Generally Accepted Risk Principles" aimed at the entire risk management process of the firm. 
than below average performance is punished. The driving force behind this nonlinearity is presumably the limited information that investors have on fund performance. Funds typically report their holdings quarterly, and popular comparisons of fund performance that are available to investors at a low cost use annual performance data.

As a consequence, fund managers face a convex incentive contract. Managers whose performance to date has been average have an incentive to increase risk in the last quarter of the year. Fund managers who have outperformed in the first three quarters of the year have an incentive to reduce risk in the fourth quarter. Chevalier and Ellison find evidence of such behavior. Obviously, this behavior is a negative feature of the principal-agent relationship between investors and fund managers and is not motivated by economic efficiency.

The inefficient behavior is driven by the nonlinear relationship between annual performance and fund inflows, which in turn is due to a lack of information on the part of investors. This suggests a role for risk management information systems. If investors could be provided with a low cost way to monitor their agents (fund managers) more frequently, the inefficiency caused by fund managers' risk-shifting in the last quarter of the year could be

eliminated. Again, this would require mutual fund firms making information from their internal systems available to fund shareholders. As we discussed elsewhere in the paper, this would be made more feasible by a greater degree of standardization of reporting on risk positions.

\section{Risk management information systems and the organization of financial firms}

In this part of the paper, we examine the implications of risk management information systems for the organization of financial firms. The cost of assembling and transmitting 
information is only one factor among many that determine a financial firm's choice of organizational structure, but there are reasons to think information is a particularly important factor. The present organizational structures of financial firms were chosen in an age when it would have been prohibitively costly to assemble accurate, timely information on risk-taking. As technological change makes it less costly to assemble information, organization structures might evolve.

A historical example of the impact of the cost of information on firms' organization at the time of the Industrial Revolution may provide a useful analogy for the current circumstances of financial dealer firms coping with the Computer Revolution. Johnson (1991) discusses how metalworking shops around the turn of the $20^{\text {th }}$ century dealt with the increasingly complex problem of estimating the cost of production of the various products they produced. Allocating overhead costs was a key problem. One approach, associated with the writings of A. H. Church, was to collect detailed information on the resources used to make different products. A few firms tried this approach but failed. As Johnson (1991, p. 55) says, "the cost of gathering and compiling such information made Church's costing procedures prohibitive in the early 1900s. However, historians have noted how Church's costing methods resembled activity-based costing techniques made possible in the 1980s by the advent of powerful personal computers."

Firms responded to the prohibitively high cost of gathering desirable information on product costs by changing their organizational structure to make that information less important. Johnson (1991) describes two such responses. One was to give up on costing out individual products, provide a "full product line," and measure profitability on a firmwide, not productspecific, basis. The other, pursued by firms such as General Motors and DuPont, was to 
decentralize decision-making by breaking up the firm into smaller units (divisions).

Johnson (1991, p. 56) argues that "perhaps multidivisional structures would never have become popular if the computer hardware and software technology of the 1980s ... had been available in the early 1900s."

A similar statement on the response to the high cost of assembling information could have been made about financial dealer firms in the 1970s and 1980s. Financial firms seem to have employed both of the approaches described above to the high cost of assembling information on risk-taking activities in the past. Firms adopted decentralized organizational structures, with different divisions responsible for risk-taking in different markets (fixed income, currencies, commodities, equities) or different products (loans, bonds, "plain vanilla" derivatives, "exotic" derivatives). Some firms touted their ability to provide a "full product line" of financial services to their customers, and uncertain margins on some products would be justified by citing the profitability of the "overall relationship."

In the future, as the cost of assembling risk information falls, it is likely that financial firms will change their organization in response. Those changes would likely reverse the two developments described above. It is likely that firms will increasingly charge prices for individual products based on each product's risk characteristics. Instead of pursuing a "full product line" approach, niche markets can be targeted. Centralized decision-making on risk positions will become feasible (just as General Motors has recently centralized its auto design and parts procurement). Given the desirability of centralization of risk information, as noted earlier, that will likely accelerate as well. 
Another organizational decision made by financial firms is whether to organize many activities (commercial banking, investment banking, insurance, securities broking, proprietary trading) within one firm as a conglomerate. Boot and Schmeits (1998) study this decision. They characterize the conglomeration decision as a tradeoff between the risk-reduction benefit of diversification and the cost of weaker incentives. Incentives are weaker in conglomerates, in their model, because internal capital allocation schemes are less effective than market discipline at motivating managers.

This framing of the conglomeration decision presents two ways that improved risk management information systems could matter. First, risk management information systems could improve internal capital allocation decisions, along the lines of what was discussed earlier in this paper. Increased centralization could contribute to this process. Second, also as discussed earlier in this paper, risk management information systems could improve market discipline by making it less costly for a firm to convey information outside the firm, reducing asymmetric information between insiders and outsiders. Based on the discussion of both these issues earlier in this paper, I conjecture that the effects of risk management information systems will be greater in the short run on firms' internal capital allocation schemes, improving the prospects for conglomeration. In the long run, risk management information systems may facilitate providing more information to those outside the firm, shifting away from conglomeration towards standalone specialist firms. 


\section{Conclusions}

We have considered a wide variety of topics under the headings of capital structure, capital budgeting, incentive compensation, and risk management looking for insights about the implications of risk management information systems. We asked what changes are likely to occur as the price of computing technology and telecommunications continues to fall, reducing the cost of assembling and managing risk information.

There were several recurring themes. Within a financial dealer firm, we might expect there to be a greater degree of centralization, both of information on risk positions and of decision-making authority. Incentive compensation schemes may become less high-powered. It may be less desirable for financial firms to hire risk-loving traders when risk is controlled more centrally. Looking beyond the boundary of a firm, we might expect firms to continue to improve their disclosures to investors, although this process could be slowed by concerns about revealing proprietary trading strategies. In the long run, we might expect it to be easier for firms in niche markets to raise funds in a world where information asymmetries are reduced. All of these factors should lead to the ultimate payoff of increasing the efficiency of financial firms and the financial system as a whole. 


\section{$\underline{\text { References }}$}

Bank for International Settlements, 1997, "Survey of disclosures about trading and derivatives activities of banks and securities firms," Joint report by the Basle Committee on Banking Supervision and the Technical Committee of the International Organisation of Securities Commissions.

Boot, Arnoud W.A. and Anjolein Schmeits, 1998, "Market discipline and incentive problems in conglomerate banks," CEPR Discussion Paper No. 1949.

Chevalier, Judith and Glenn Ellison, 1997, "Risk taking by mutual funds as a response to incentives," Journal of Political Economy 105, 1167-1200.

Diamond, Douglas W. and Robert E. Verrecchia. 1991, "Disclosure, liquidity, and the cost of capital," Journal of Finance 46, 1325-1359.

Froot, Kenneth A. and Jeremy C. Stein, 1998, "Risk management, capital budgeting, and capital structure policy for financial institutions: an integrated approach," Journal of Financial Economics 47, 55-82.

Gibson, Michael S., 1997, "Information systems for risk management," in Bank for International Settlements, The Measurement of Aggregate Market Risk, 115-132.

Harris, Milton and Artur Raviv, 1996, "The capital budgeting process: incentives and information," Journal of Finance 51, 1139-1174.

Hirshleifer, David and Yoon Suh, 1992, "Risk, managerial effort, and project choice," Journal of Financial Intermediation 2, 308-345. 
Johnson, H. Thomas, 1991, "Managing by remote control: Recent management accounting practice in historical perspective," in Peter Temin, ed., Inside the Business Enterprise, Chicago: University of Chicago Press for NBER.

Masulis, Ronald W., 1988, The Debt/Equity Choice, Cambridge, MA: Ballinger.

Myers, Stewart C. and Nicholas S. Majluf, 1984, "Corporate financing and investment decisions when firms have information that investors do not have," Journal of Financial Economics $13,187-221$.

Pritsker, Matthew, 1997, "Evaluating Value at Risk methodologies: Accuracy versus computational time," Journal of Financial Services Research 12, 201-241. 